УДК $347.2 / 3$

\author{
П. Д. Гуйван \\ кандидат юридичних наук, заслужений юрист України, \\ докторант \\ Національного юридичного університету імені Ярослава Мудрого
}

\title{
ОБЧИСЛЕННЯ ПОЗОВНОЇ ДАВНОСТІ ПІСЛЯ ПРЕД'ЯВЛЕННЯ ПОЗОВУ: ЧИННЕ ЗАКОНОДАВСТВО ТА ЙОГО ТЛУМАЧЕННЯ
}

Зупинення позовного строку зумовлюється обставинами, що не залежать від волевиявлення не тільки учасників цивільного відношення, а й юрисдикційного органу. Навпаки, переривання давності відбувається завжди в результаті активних дій суб'єктів - управненої або зобов'язаної особи. У результаті зупинення строку давності сумарна його тривалість все одно не перевищуватиме величин, встановлених у статтях 257-259 ЦКУ. Натомість переривання позовної давності призводить до фактичного її подовження, позаяк час, що сплив до переривання, не зараховується до нового строку. У такому разі цілком можлива ситуація, коли сумарна тривалість давності, що реально спливла, у разі іï переривання буде більшою від встановленої для таких вимог. Проте нову давність не можна вважати продовженням попередньої, після переривання від самого початку починається новий перебіг. Своєю чергою переривання давності може здійснитися лише до її закінчення, отже, позовна давність, що перервалася, завжди буде меншою за визначений відповідно до законодавства строк.

Із передбачених ст. 264 ЦК двох підстав для переривання перебігу давнісного строку особливий інтерес викликає пред'явлення носієм порушеного суб'єктивного права судового позову до порушника у встановленому порядку. Актуальність питання зумовлена тривалими спробами законодавця унормувати цей процес, аби забезпечити адекватний та співмірний правовий захист матеріальних прав особи в конкретних юридичних ситуаціях. Вважаємо, що порівняно із численними нормативними правилами, що регулювали обчислення позовної давності в разі пред'явлення позову раніше, чинна редакція ч. 2 ст. 264 ЦКУ $\epsilon$ найбільш правильною. Але, як відомо, ефективність правового припису проявляється у його розумінні учасниками відносин та, зрештою, у належному правозастосуванні. Ось тут на рівні правоусвідомлення сутності регулюючого механізму відбувається пробуксовка. Вона значною мірою грунтується на усталеній ментальності наших правників, які взагалі не можуть уявити, що із належним пред'явленням позову право на таке ж саме за обсягом і адресатом домагання втрачається, бо є вже реалізованим, незалежно від змісту майбутнього рішення (позов задоволено чи відмовлено у ньому, закрите провадження), і строк реалізації матеріального права на позов достроково припинився з огляду на вичерпаність самого права і неможливість його повторного здійснення.

Доктринальні дослідження питання переважно обмежуються простою констатацією факту: позовна давність переривається пред'явленням позову, не вдаючись до аналізу наслідків такого переривання для подальшого давнісного перебігу. Скажімо, М. Кириллова та П. Крашенинніков вказують, що в усіх випадках зупинення провадження позовна давність переривається вже в момент пред'явлення позову і не відновлюється на весь період розгляду справи $[1$, с. 39$]$. Тезу про загальність правила стосовно початку нового перебігу внаслідок переривання давнісного строку у разі пред'явлення позову обстоюють також О. Святогор, Р. Куссмауль, В. Самойленко, Л. Вострикова та інші.

На жаль, відсутність більш широкого усталеного тлумачення відповідної статті законодавства на рівні наукової концепції призводить до численних різнобачень юридичної сутності коментованого правила та, що найприкріше, до поширених і невиправданих помилок у його практичному застосуванні. Відсутність належного аналізу наслідків пред'явленого позову в контексті переривання позовної давності призводить до очевидно неправильних висловлювань на кшталт: «після пред'явлення позову починається новий перебіг позовної давності за тими ж вимогами стосовно того ж боржника». Іноді доводиться зустрічати навіть твердження, що цей новий перебіг триває незалежно від вирішення судового спору по суті, тобто і тоді, коли буде прийняте рішення. В кращому разі окремі дослідники, визнаючи наявність зазначеного нового перебігу давнісного строку після пред'явлення позову, все ж ставлять під сумнів доцільність його правового запровадження [2, с. 17].

Теза про переривання давнісного перебігу із пред'явленням позову за тими ж вимогами набула поширення не лише в юридичній доктрині, вона має місце і в правозастосовній практиці. Такий підхід у корні неправильний, ба більше того, він $є$ небезпечний, бо на практиці може призвести до захисту того права, яке не може бути захищеним і у такий спосіб спотворити основоположну ідею юридичної визначеності як елемента верховенства права, закладену колись в основу запровадження інституту позовної давності. 
Приміром, Касаційний цивільний суд Верховного Суду у постанові від 23 травня 2018 року у справі № 663/2070/15-ц, цілком слушно прокоментувавши законодавче правило ч. 2 ст. 264 ЦКУ стосовно того, що позовна давність переривається у разі пред'явлення особою позову до одного із кількох боржників, а також якщо предметом позову є лише частина вимоги, право на яку має позивач, все ж чомусь вирішив, що із пред'явленням кредитною спілкою позову до відповідачів про стягнення кредитної заборгованості у листопаді 2010 року перебіг позовної давності перервався, тож визначив нову дату початку перебігу позовної давності після iї переривання за тією ж вимогою до відповідача. Подібне трактування закону є відверто неправильним [3]. Отже, теоретичне напрацювання адекватного правового інструментарію застосування темпоральних наслідків для існування матеріального права на позов після пред'явлення судового домагання та виявлення реальної сутності відповідного юридичного правила є завданням цієї праці.

Зміст інституту позовної давності можна зрозуміти, лише якщо усвідомити юридичний та фактичний стан тих відносин, що ним регулюються. При цьому предметом дослідження стають такі питання: за яких обставин, за якими вимогами та в який момент відбувається переривання позовної давності у разі звернення особи до суду? коли закінчується цей новий період? зрештою, яка природа такого нового строку, тривалість якого матеріального цивільного права він опосередкує? На них намагалися дати відповідь численні дослідники. Більшість правників, котрі нині вважають, що позовна давність за тими ж вимогами до того ж боржника переривається в момент пред'явлення позову, виходячи з цієї тези, будують подальші правові конструкції. Так, Р. Куссмауль зазначає, що під час зміни підстави позову давність за пред'явленою вимогою переривається від часу подання заяви про таку зміну. Втім, далі автор, суперечачи собі, вказує, що у разі зміни підстави позову захищається вже зовсім інше порушене право. Виникає інша вимога, яка почала задавнюватися від виникнення права на неї, тобто від часу такого конкретного правопорушення [4, с. 21-22]. Така позиція частково заслуговує на увагу: справді, зміна підстави позову може кваліфікуватися як пред'явлення до відповідача в тому ж процесі іншої вимоги. Інша річ, що сама можливість замінити вимогу в тому ж процесі нам видається недоцільною, та це вже питання до законодавця. Зрештою, з огляду на новітне процесуальне законодавство, в якому можливість зміни підстави чи предмета позову обмежена часом до початку розгляду судом справи по суті (ч. 3 ст. 49 ЦПКУ), законодавець переймається цим питанням. Крім того, варто вказати, що перебіг давності за зміненою вимогою почнеться з моменту порушення ре- гулятивного права (тобто за загальним правилом), а не від часу її пред'явлення в суді.

Ще більшої невизначеності у цьому питанні додасться, якщо почати з'ясовувати, яким усе-таки чином відбувається новий перебіг позовної давності після того, як буде належно пред'явлено позов, та як цей перебіг буде надалі впливати на можливість захисту права упродовж триваючого процесу. В усякому разі ті вчені, які припускають існування нового перебігу, прийнятного тлумачення на цю тему не пропонують. Так, М. Ринг каже, що такий сплив нового давнісного строку не може призвести до відмови у позові [5, с. 21], проте не зазначає, яке ж його юридичне призначення. В. Луць, зазначаючи про початок нового перебігу давності після пред'явлення позову, вказує на можливість суду чи інстанції, яка переглядає справу, у разі його спливу відновити позовну давність [6, с. 55]. Отже, йдеться про можливість давнісного перебігу і навіть закінчення цього строку протягом судового розгляду спору. Але в такому разі позовна давність позбавляється свого основного значення як періоду для захисту права за зверненням управненої особи.

Окремі дослідники, ставлячи цілком логічне за таких обставин питання про безглуздість нового перебігу позовної давності, оскільки під час вирішення судового спору, новий позов (а саме для реалізації права на позов і запроваджується позовна давність) аналогічного змісту до тієї ж особи стає неможливим через пряму вказівку закону, все ж намагаються штучно створити правову ситуацію, яка б хоч якоюсь мірою пояснювала теорію про переривання давності із пред'явленням позову. В результаті отримуємо твердження, що позовна давність у разі пред'явлення позову переривається не для позивача, а для відповідача [2, с. 17]. Така концепція не витримує критики насамперед тому, що за визначенням закону перебіг позовної давності (і відповідно, порядок ії обчислення) відбувається відносно вимог, які належать кредиторові щодо захисту його порушених суб'єктивних прав. Відповідач у судовому процесі теж може бути наділений певними суб'єктивними правами стосовно позивача. У такому разі він виступає в цьому правовідношенні як кредитор, і за його зустрічними відповідними вимогами почнеться давнісний перебіг, обчислення якого відбуватиметься за загальним правилом.

Як бачимо, в описаних ситуаціях відсутні підстави для переривання позовної давності із пред'явленням позову. Однак ч. 2 ст. 264 ЦКУ все-таки каже про таке переривання. Тож, виходячи із сутності опосередкованих таким правовим інститутом відносин, необхідно визначитися, як і за яких умов переривається позовна давність із пред'явленням позову і чи переривається вона взагалі? Коли це так, то якого змісту і до кого має бути пред'явлений вказаний позов? Якщо припустити, 
що у будь-якому разі після пред'явлення позову починається новий давнісний перебіг, цілком закономірно виникає питання: яке призначення має вказаний строк? Він не може бути строком реалізації права на отримання судового захисту, позаяк вказане право вже реалізоване. Двічі захистити одне й те ж право від того ж порушення неможливо, та в цьому, власне, немає потреби. Фактично позовна давність, що спливає за тими ж вимогами після пред'явлення позову обмежує в часі право особи, яке припинило своє існування. Адже право на позов (власне, саме його тривалість і регулюється позовною давністю) буде вже реалізованим.

Раніше вказувалось, що більшість дослідників цього питання замість аналізу практичних наслідків можливого переривання давнісного строку в результаті пред'явленого позову спрощують проблему, фактично відмовляючись від постановки питань «навіщо» та «яким чином» за наявності прямої імперативної вказівки закону про новий початок позовної давності [7, с. 157]. У кращому разі, коли такий аналіз все-таки здійснюється, міркування авторів зводяться приблизно до такого: протягом нового давнісного перебігу позивач може пред' явити інші за змістом вимоги до того ж відповідача або вимоги до інших осіб 3 іншим предметом [8, с. 10-11]. Дозволимо собі не погодитися з такою позицією.

Оцінимо чинний правовий механізм щодо досліджуваного питання та його дієвість. По-перше, далеко не всі акти законодавства є ідеальними, не буде винятком у цьому відношенні і коментований інститут Цивільного кодексу. Отже, задача ï подальшого коригування у разі виявлення невідповідності регулятивного механізму справжній сутності опосередкованих відносин $є$ досить прогресивною. По-друге, нинішня редакція ч. 2 ст. 264 ЦКУ (на відміну від їі попередниці ст. 79 ЦК УРСР) далебі не виглядає однозначним імперативним правилом навіть на перший погляд. Очевидно, що вона потребує як додаткового тлумачення, так i, можливо, деякого коригування. Давайте більш ретельно придивимося до зовнішньої оболонки цієї правової норми (буквального тексту правила, що в ній міститься) та спробуймо виявити їі реальний зміст, що максимально відповідає логіці найбільш бажаної поведінки учасників відповідного правовідношення. При цьому не можна відкидати й того, що отримане в результаті нашого дослідження тлумачення конкретного змісту правила частини 2 статті 264 ЦКУ буде відрізнятися від закладеного у цей же текст самим законодавцем. Головне, щоб висловлене в законі правило було дієвим та ефективним, а не заводило реальні взаємини до тупикового стану.

Отже, закон стверджує, що з пред'явленням позову до одного із кількох боржників, а також якщо предметом позову є лише частина вимоги, право на яку має позивач, позовна давність переривається, після чого починається новий її перебіг. Можна погодитися, така норма не є ідеальним правовим регулятором. Але її недоліки щодо нечіткості визначень можна поділити на дві категорії. Перші з них усуваються шляхом логічного правозастосування тексту самими учасниками відносин, позаяк інший механізм використання норми просто суперечив би здоровому глузду. Скажімо, ніхто не сумнівається, що в законі йдеться про те, що у разі пред'явлення позову до одного з боржників відбувається переривання давності за вимогали до інших. Так само безспірно виглядає тлумачення такої норми стосовно переривання давності за вимогами шодо іншої частини борәу, ніж та, про яку заявлено у позові.

Інші наслідки недостатньої чіткості та визначеності коментованої норми вже не такі безпечні. Зокрема, по-різному оцінюється дослідниками питання про те, чи переривається під час пред'явлення позову давнісний строк до того ж боржника (відповідача) за тими ж вимогами кредитора (позивача). Одні з них вважають, що так [9, с. 7] (як ми вже зазначали, більшість правників саме так піддає розширеному тлумаченню вказане нормативне правило), інші вказують на досить обмежену можливість такого правового результату, що настає лише за певних обставин [10, с. 109]. Останнім часом у літературі була висловлена і третя позиція, яка зводиться до такого: під час пред'явлення позову перебіг позовної давності за тими ж вимогами до того ж боржника не переривається [11, с. 13]. Як би це не здавалося дивним на перший погляд, але саме це тлумачення найбільш відповідає дійсному призначенню коментованої норми, але обов'язково з відповідним уточненням. Адже з прямого розуміння сенсу концепції можна дійти хибного висновку, що давність, якщо вона 3 пред'явленням позову не переривається, триває до свого номінального закінчення. То не так, як уже неодноразово нами доводилося в інших працях: після реалізації матеріального права на позов перебіг позовної давності, як і існування обмеженого нею в часі матеріального права, достроково припиняється з огляду на вичерпаність здійсненого повноваження. Проте для надання цьому правовому підходу статусу офіційного необхідно, як мінімум, здійснити певні законодавчі коригування, що давно назріли.

До аргументів на користь саме такого тлумачення переривання давності із пред'явленням позову можна віднести і подальші зміни у цивільному законодавстві зарубіжних країн, що були здійснені нещодавно, і міжнародні правові акти. Так, у Цивільному кодексі РФ взагалі виключено правило про можливість переривання позовної давності із пред'явленням позову. За змістом статті 203 ЦК РФ нині давнісний перебіг за певними вимогами 
кредитора до боржника переривається виключно внаслідок вчинення боржником певної дії, яку можна кваліфікувати як визнання боргу. Таке загалом правильне рішення законодавця виглядає все ж занадто радикальним. Вважаємо більш правильний та виважений підхід обрав український нормотворець. Адже не можна зовсім виключати ситуацій, коли 3 якихось суб'єктивних чи об'єктивних обставин носій охоронного права на позов може пред'явити судове домагання не за всією сумою обов'язку або не до всіх солідарних боржників, зобов'язаних за неподільним боргом. У такому разі вельми справедливим буде правило про переривання давнісного перебігу за рештою вимог або стосовно боржників, не охоплених домаганням. Але то може застосовуватися лише як виняток із загального правового інструментарію, за яким переривання давності під час пред'явлення позову за тими ж вимогами до того ж відповідача неприпустиме. Позовна давність достроково припиняється, як i будь-який строк у момент своєчасного здійснення обмеженого нею в часі суб'єктивного права.

Певне підтвердження нашої позиції щодо припинення давнісного строку після пред'явлення позову знаходимо і в тексті Нью-Йоркської Конвенції. Незважаючи на те, що в цьому документі йдеться про переривання позовної давності у разі здійснення кредитором дій, які за правом країни суду, де порушується справа, розглядається як початок судового розгляду проти боржника, в ньому відсутні вказівки про початок нового давнісного перебігу [12, с. 93]. Можна припустити, що в цьому контексті поняття переривання позовної давності ототожнювалося авторами документа з його припиненням. Ця теза виглядає тим більш логічною, що у статті 20 Конвенції йдеться не про переривання давності у разі вчинення дій, що свідчать про визнання боргу, а про початок нового давнісного строку. Отже, можемо дійти висновку про те, що за логікою цього документа початок нового перебігу і переривання позовної давності різносенсові поняття.

3 викладеного в цій статті слід зробити деякі висновки. Можемо чітко сказати, що в правозастосовній практиці не має виникати ситуацій, коли пред'явлення позову матиме наслідком переривання позовної давності за тими ж вимогами до того ж відповідача, незалежно від того, яким чином завершився судовий процес. Отже, єдино можливою для переривання перебігу давнісного строку пред'явлення позову є ситуація, коли позов пред'явлено до одного з кількох боржників або, коли предметом позову є лише частина вимоги, право на яку має кредитор. Але повторимо, позовна давність переривається щодо вимог до інших, ніж відповідач, осіб та з іншим предметом. 3 огляду на це положення частини 2 ст. 264 ЦКУ слід визнати викладеними правильно, вони кардинально змінили невдалу редакцію, що містила- ся у ст. 79 ЦК УРСР. Тому залишається незрозумілим, чому, коментуючи цілком очевидний зміст вказаної норми, більшість дослідників знову вказує на загальність правила: переривання позовної давності переривається у разі пред'явлення позову з вимогою про погашення боргу або виконання іншого обов'язку. Тлумачення на кшталт наведеного не відповідають нині ні чинному законодавству, ні реальній сутності коментованих відносин.

\section{Jimepamypa}

1. Кириллова М.Я., Крашенинников П.В. Сроки в гражданском праве. Исковая давность. Москва : Статут, $2006.48 \mathrm{c}$.

2. Миргородский Д. Применение ГК в вексельных спорах. Сроки давности в вексельных отношениях: практическое толкование статьи 79 ГК УССР. Юридическая практика. 2003. № 37. С. 17.

3. Постанова Касаційного цивільного суду Верховного Суду від 23.05.2018 року у справі № 663/ 2070/15-ц. URL: http://www.reyestr.court.gov.ua/ Review/74475626.

4. Куссмауль Р. Процессуальные вопросы применения исковой давности. Российская юстииия. 2000. № 2. C. 21-26.

5. Ринг М.П. Исковая давность в новом Гражданском кодексе РСФСР. Советская юстиция. 1964. № 19. C. $18-23$.

6. Луць В.В. Строки захисту цивільних прав. Конспекти лекцій зі спецкурсу. Львів : ЛДУ, 1993. 60 с.

7. Харитонов Е.О. Гражданский кодекс Украины. Научно-практический комментарий. Харьков : Одиссей, $1999.544 \mathrm{c}$.

8. Самойленко В. Прерывание срока исковой давности. Юридическая практика. 2003. № 39. С. 10-11.

9. Бежевец О., Михайлова О. Вопросы проблемного долга. Юридическая практика. 2003. № 24. С. 1-7.

10. Горовець С. Переривання позовної давності: сутність і призначення. Юридичний журнал. 2005. № 12 (42). С. 102-111.

11. Михайленко Д. Исковая давность в действующем ГК. Проблемы прерывания исковой давности при подаче искового заявления. Юридическая практика. 2004. № 46. С. 13.

12. Гаркуша Л. Исковая давность по внешнеэкономическим сделкам купли-продажи. Бизнес. 2000. № 46. С. 92-95.

\section{Анотація}

Гуйван П. Д. Обчислення позовної давності після пред'явлення позову: чинне законодавство та його тлумачення. - Стаття.

У статті проведено дослідження реальної правової природи матеріального суб'єктивного права особи на позов. Вивчено темпоральні аспекти, що пов'язані з тривалістю здійснення позовного домагання. Приділено особливу увагу аналізу перебігу давнісного строку після пред'явлення позову. В роботі доводиться помилковість поширеної в науці та правозастосовній практиці тези про переривання давнісного перебігу із пред'явленням позову за тими ж вимогами. Такий підхід неправильний, бо на практиці може призвести до захисту того права, яке не може бути захищеним і у такий спосіб спотворити основоположну ідею юридичної визначеності як елемента верховенства права, закладену колись в основу запровадження інституту позовної давності. Піддано обгрунтованій критиці 
положення про те, що у разі зміни підстави позову давність за пред'явленою вимогою переривається від часу подання заяви про таку зміну. Адже у разі зміни підстави позову захищається вже зовсім інше порушене право, виникає інша вимога, яка почала задавнюватися від виникнення права на неї, тобто від часу конкретного правопорушення.

За наслідками дослідження зроблений висновок, що новий позов аналогічного змісту до тієї ж особи після пред'явлення домагання стає неможливим через пряму вказівку закону. Разом із тим встановлено, що давність переривається тільки у виключних випадках, коли судові вимоги пред'явлені не за всім обсягом обов'язку та не до всіх боржників. Таке переривання відбувається лише стосовно охоронно-правових вимог, не охоплених змістом та спрямованістю позову. Це відбувається, коли 3 якихось суб'єктивних чи об'єктивних обставин носій охоронного права на позов може пред'явити судове домагання не за всією сумою обов'язку або не до всіх солідарних боржників, зобов'язаних за неподільним боргом. У такому разі вельми справедливим буде правило про переривання давнісного перебігу за рештою вимог або стосовно боржників, не охоплених домаганням. Але то може застосовуватися лише як виняток із загального правового інструментарію, за яким переривання давності під час пред'явлення позову за тими ж вимогами до того ж відповідача неприпустиме.

В інших випадках переривання не буде, а позовна давність достроково припиняється, як і будь-який строк у момент своєчасного здійснення обмеженого нею в часі суб'єктивного права.

Ключові слова: припинення позовної давності, позовне домагання.

\section{Summary}

Guyvan P. D. The calculation of the statute of limitations after filing a claim: current legislation and its practical interpretation. - Article.

The article conducted a study of the real legal nature of the material subjective right of a person to sue. Studied the temporal aspects associated with the duration of the claim. Particular attention is paid to the analysis of the period of limitation after the filing of a claim. The paper proves the fallacy of the thesis on the interruption of the prescriptive pressure that is widespread in science and law-enforcement practice with the filing of a lawsuit according to the same requirements. Such an approach is wrong, because in practice it can lead to the protection of that right that cannot be protected and thus distort the fundamental idea of legal certainty as an element of the rule of law that once laid the foundation for the introduction of the institution of limitation. Subject to justified criticism is the provision that when the basis of the claim changes, the limitation on the claim is interrupted from the time when the application for such a change is submitted. After all, in the event of a change in the basis of a claim, a completely different right is defended, another requirement arises, which has begun to prick from the occurrence of the right to it, that is, from the time of a specific offense.

According to the results of the study, it was concluded that a new lawsuit of a similar content to the same person after the presentation of the claim becomes impossible due to the direct indication of the law. At the same time, it has been established that limitation is interrupted only in exceptional cases, when court claims are made not for the entire amount of the debt and not for all debtors. Such an interruption occurs only in respect of the legal requirements that are not covered by the content and focus of the claim. This occurs when, for some subjective or objective circumstances, the bearer of the protective right to a claim may bring a court claim not for the entire amount of the debt, or not for all joint and several debtors who are obliged for an indivisible debt. In such a case, the rule on the termination of the prescriptive period for the remaining claims or for debtors not covered by harassment will be very fair. But, this can be used only as an exception to the general legal instruments, according to which a break of prescription when filing a claim for the same requirements to the same respondent is unacceptable.

In other cases, there will be no interruption, and the limitation of actions early terminates, as well as any precautionary period at the time of the timely exercise of a subjective right limited in time. claim. 